\title{
Coping with the events of daily life and quality of life of the socially active elderly
}

\begin{abstract}
BACKGROUND
Late adulthood is a period in which the number of stressors is increasing; therefore, strategies of coping with these situations may be significant in terms of the subjective evaluation of the quality of life and adaptation to old age. The objective of this paper was to examine the relationships between proactive coping and the quality of life in people in late adulthood. The quality of life was assessed using the Polish version of the CASP-19.
\end{abstract}

\section{PARTICIPANTS AND PROCEDURE}

The research included 88 individuals (76 women and 12 men), aged from 60 to 85 years $(M=69.5, S D=6.74)$. The following tools were used: The Proactive Coping Inventory, developed by Greenglass, Schwarzer and Taubert (Pasikowski's adaptation), and the scale for the assessment of the quality of life, called CASP-19, of Higgs, Hyde, Wiggins and Blane (developed by the authors of this paper).

\section{RESULTS}

The results of the research showed a positive relationship between the general level of proactive coping strategies, the proactive coping subscale and the general quality of life and addressing the needs of control and pleasure. People who are more proactive accomplish a higher general level of the quality of life, control and pleasure than people whose pro-activity level is lower.

\section{CONCLUSIONS}

Factors contributing to the quality of life and successful aging of elderly subjects are, first and foremost, skills connected with setting objectives autonomously, taking initiative, perseverance in activities and perceiving events in terms of opportunities of development and self-improvement. The CASP-19 seems to be a useful measure of the quality of life in old age.

KEY WORDS

old age; proactive coping; quality of life; CASP-19

ORganizations - Department of Clinical Psychology, John Paul II Catholic University of Lublin, Poland AUthors' CONtribution - A: Study design - B: Data collection - C: Statistical analysis - D: Data interpretation .

E: Manuscript preparation · F: Literature search · G: Funds collection 


\section{BACKGROUND}

The objective of this study is to conduct an assessment of the association between the way of coping with the events of daily life and the quality of life of the (socially active) elderly, estimated using the Polish version of the CASP-19 scale of Higgs, Hyde, Wiggins and Blane (2003).

Anna Gamrowska, Stanisława Steuden

Late adulthood is a period in which the number of stressors, particularly in the category of the loss of important values (Meléndez, Mayordomo, Sancho \& Tomás, 2012; Steuden, 2009, 2011; Steuden \& Marczuk, 2006; Straś-Romanowska, 2002; SzaturJaworska, Błędowski \& Dzięgielewska, 2006), increases, but coping with them is an ability formed on the basis of earlier experiences in one's life. For the elderly, the difficult thing is to cope with daily responsibilities, social and cultural changes, their own emotions and changes to social roles (Diehl et al., 2013). In recent years, research into old age has been concentrating not only on the inconveniences connected with age, but also on showing the different aspects of the potential of the elderly. Adaptation to old age and the sense of the quality of life are connected with the ability to activate personal and social resources. The data in the literature of the subject support the conclusion that the way of coping with daily difficulties is determined by a number of factors; it is dependent on biological, psychological and situational factors (Diehl et al., 2013; Lazarus, 1986; Meléndez et al., 2012; Trouillet, Doan-Van-Hay, Launay \& Martin, 2011; Wrześniewski, 2000).

An aspect that is important and deserves to be taken into consideration as well is the temporal one, concerning remedial behaviours in relation to difficult past events, either in the course of them, or before they actually occurred. A new way of perceiving them in comparison with the hitherto well-established concepts of coping with stress (among others, of Endler \& Parker, 1994; Hobfoll, 1989; Lazarus \& Folkman, 1984) can be found in the concept of proactive coping developed by Schwarzer and Taubert (1999). This is based on the two dimensions determining the degree of likelihood and the time of the occurrence of a stressor, and it provides the possibility of separating four types of strategies of coping: reactive, anticipative, preventive and proactive. Reactive coping, similarly to what we see in the conception of Lazarus (1986), is directed at stressful situations which occurred in the past, and which are assessed as a harm or a loss. The objective of coping is striving to compensate them, or alleviate the negative results of them, by means of the reformulation of objectives or adjust- ing them to a new, positively assessed situation in life (Schwarzer \& Taubert, 1999). Anticipative, preventive and reactive strategies refer to future, anticipated threats and challenges. These events, due to the various degree of uncertainty of their occurrence, are divided into normative (for example, the age-connected lowering of psycho-physical capacity, taking retirement) and non-normative - difficult to foresee (cf. Pasikowski, Sęk, Greenglass \& Taubert, 2002). Anticipative coping is directed at normative events which are to occur in the near future, and are assessed as a threat (for example, a necessary reorganization of the former lifestyle in connection with retirement). This process is moderated by personal and social resources, and the decisive role is that of the sense of one's efficiency. Preventive coping refers to non-normative, and simultaneously uncertain and unknown, events and threats. In comparison with anticipative coping, a temporal interval between the activation of remedial strategies and the occurrence of a stressor is usually longer; therefore, gathering resources is of a more general character (Schwarzer \& Taubert, 1999). Proactive coping is "autonomous, and also independent, setting oneself objectives being challenges, and also the consistent accomplishment of them. It concerns self-regulative processes of accomplishing objectives, and strives to explain what motivates people to strive to accomplish ambitious objectives, and getting involved in self-perfecting" (Schwarzer \& Taubert, 1999, p. 86). The driving force behind proactive coping is searching for challenges which are moderated by positive motivation and the sense of one's efficiency. An individual who becomes involved in generating reasonable objectives and accomplishing them may not pay attention to stressors assessed as burdensome in a situation of the lack of orientation towards important challenges (Schwarzer \& Taubert, 1999; cf. Trouillet et al., 2011). For the purpose of the measurement of the various aspects of a proactive approach in coping, Greenglass, Schwarzer, Jakubiec, Fiksenbaum and Taubert (1999) constructed the Proactive Coping Inventory (PCI). When it was being developed, concepts placing emphasis on the significance of control, positive emotions, social support, and also proactive behaviours, in coping with difficulties were referred to. Proactive coping is viewed as an approach to life and an existential conviction that everything will finally be fine not because of luck, or factors beyond one's control, but because of the responsibility of an individual human being for their own actions and their results (Greenglass et al., 1999).

\section{QUALITY OF LIFE IN THE PERIOD OF LATE ADULTHOOD}

The majority of definitions of quality of life show that it is the result of adopting a complex, comprehensive, 
cognitive-affective approach towards one's own life in its entirety and particular dimensions (cf. Oleś, 2010; Straś-Romanowska, 2005). In reference to the elderly, the model of the quality of life of Higgs et al. (2003) is of interest. In this model, the quality of life of the elderly is a multi-dimensional phenomenon, it reflects the interactions of various factors and events in the life of an individual, it cannot be reduced to the state of health, but it should also be determined by the degree of meeting needs which are important for an individual, and also take into consideration the social-historical situations of the following generations of the elderly (Higgs et al., 2003, p. 243). The authors of this model, referring to the concept of needs of Maslow (1943), and also of Doyal and Gough (1991), adopt the assumption that for the quality of life of the elderly meeting the basic needs, which makes it possible to meet the needs of autonomy and social involvement, is of particular importance. Taking into consideration these two groups of needs made it possible to separate four dimensions of the quality of life: control, autonomy, pleasure and self-actualization. Autonomy is understood as: the possibility of making decisions relevant to oneself and the basic issues of life, ability to set adequate objectives for oneself, and also to verify the ways of accomplishing them. A sense of control is connected with the possibility of active intervention in one's own milieu. In turn, meeting the needs of autonomy and control allows further development and undertaking such forms of activity which provide a sense of pleasure and joy stemming from life, and staying among other people. Self-actualization is connected with the sense of satisfaction with the former lifestyle, optimism, and also the level of energy in one's possession. Even though pleasure and self-actualization constitute universal human needs, nevertheless, the ways of meeting them are dependent on a social-cultural context, and one's own preferences (Higgs et al., 2003, p. 246). The research conducted by Higgs et al. (2003) gives rise to the conclusion that a significant number of the elderly feel that the quality of their own life is high or average. It may be interpreted as the ability of the elderly to positively assess their own situation, in spite of numerous inconveniences connected with age. It is likely that a major significance here is that of the mechanism of selective optimization and compensation described by P. Baltes and M. Baltes (1990; cf. Steuden, 2011, pp. 72-73).

The search for the association between coping with the events of daily life and the quality of life is justified by the fact that ever more and more individuals live up to the period of old age, and also longer after reaching it (cf. CSO, 2013, pp. 121-122). The literature devoted to the period of late adulthood is ever richer, yet there are still no more in-depth analyses concerning the issues of quality of life, remedial activity, mobilizing resources by the elderly and taking advantage of them. This paper is a contribution to a rel- atively new trend in the discussion on ageing and old age which places emphasis on the possibility of the optimal adjustment and the development of the elderly, indicates varied resources making it easier to cope with difficult situations typical for this age, and also places emphasis on the responsibility of a human being for the state of this period of life (Steuden, 2011). The research conducted in the groups of healthy and ill individuals in the periods of early and middle adulthood indicates pro-activity as a significant factor in shaping pro-health attitudes, and also one conducive to satisfaction with life (Greenglass, 2002, p. 29; Greenglass et al., 1999, p. 12; Sęk \& Pasikowski, 2003, pp. 114-115; Słysz, 2004, pp. 42-43). The number of such studies devoted to the population of the elderly is relatively small. What is more, there are no methods for estimating the quality of life taking into consideration the specific character of this period of life. This paper is a proposal of meeting halfway the need to search for the factors conducive to successful ageing, and strengthening the subjective quality of life of seniors, but it is also an attempt to present a new tool for measuring the quality of life of the elderly.

\section{RESEARCH QUESTION AND RESEARCH HYPOTHESES}

The objective of the research was to search for an association between proactive strategies of coping with the events of daily life and the sense of the quality of life in socially active elderly. This is because the activity of the elderly is governed by the principle of feedback - on the one hand, this is an expression of a positive reaction to the tasks connected with this period of life, and, on the other hand, it strengthens the self-esteem and becomes the driving force behind further development (cf. Steuden, 2011, p. 82).

The research questions which this paper addresses are as follows:

1. What relations are there between proactive reme-

dial strategies and the quality of life of the elderly?

Proactive coping is identified by use of the general indicator, and also detailed strategies (proactive, reflective, strategic planning, preventive, searching for instrumental support, searching for emotional support, and also coping by avoidance). The quality of life is determined on the basis of the general indicator and four dimensions (control, autonomy, pleasure and self-actualization).

2. Do individuals having a high level of global proactive coping differ from individuals having a low level of such coping in the scope of quality of life?

Concerning the first question, the following research hypotheses were formulated:

H.1. The proactive strategy of coping is coexistent with the satisfied needs of control, autonomy, self-actualization and pleasure.
Coping and quality of life in the elderly 
Anna Gamrowska,

Stanisława Steuden
On the basis of the analysis of the literature of the subject, it is possible to assume that proactive coping, consisting in setting ambitious objectives for oneself independently and autonomously (cf. Greenglass et al., 1999; Schwarzer \& Taubert, 1999), leads to satisfying the needs of control, autonomy, self-actualization and pleasure (cf. Higgs et al., 2003). Undertaking activity in life makes it possible for the elderly to maintain the sense of significance, self-esteem, and satisfaction with life, and also to exercise control over it (Steuden, 2009, p. 39; cf. Ouwehand, De Ridder \& Bensing, 2007). H.2. There exists a positive association between searching for emotional support and the need of pleasure.

The analysis of the literature of the subject leads to the conclusion that searching for social support is an effective strategy of coping, and is conducive to the welfare of a person (cf. Greenglass, 2002, pp. 44-46; Greenglass \& Fiksenbaum, 2009, pp. 37-38). The research conducted in the field of positive psychology also gives rise to the conclusion that positive relationships with other people, encompassing strength, pleasure, and also the joy which results from authentic and deep social bonds, are one of the dimensions of mental welfare (Ryff \& Singer, 2004, pp. 154-156). What is more, addressing another person with a request for help in a difficult situation is considered an active, and usually adjustment, strategy of coping (Knoll \& Schwarzer, 2006, p. 46) because support, being provided at the same time as a stressor is being experienced, improves mood (Schwarzer \& Leppin, 1988, quoting: Sęk \& Cieślak, 2006, p. 27).

H.3. There exists a negative association between coping by avoidance and the general indicator of the quality of life.

The results of research in this field are divergent; the research of Sęk and Pasikowski (2003, p. 115) and Słysz (2004, p. 42) gives rise to the conclusion that there exists a negative association between the avoidance strategy of coping and the subjective indicators of mental and social health, and also the resources of health. The lack of significant associations between coping by avoidance and depression was ascertained in the research conducted by Greenglass et al. (1999, p. 12), and the same conclusion was reached in the case of coping by avoidance and satisfaction with life (Brzezińska \& Steuden, 2011, p. 140). Therefore, it may be assumed that refraining from undertaking actions and distancing oneself from problems is not conducive to the welfare of a person, and it may co-occur with a lower quality of life.

Concerning the second question, the following hypothesis is put forward:

H.4. A higher global level of proactive remedial behaviours co-occurs with a higher level of the sense of the quality of life.

The analysis of the literature gives rise to the conclusion that coping and the quality of life are vari- ables which may exert a mutual influence on one another. The research conducted to date shows that the proactive strategies of coping (except for coping by avoidance) are positively connected with the following subjective indicators: of health (somatic, mental, social, and also the resources of health), satisfaction with life, the quality of life, and also with optimism (Brzezińska \& Steuden, 2011, pp. 139-140; Greenglass et al., 1999, p. 12; Sęk \& Pasikowski, 2003, pp. 114-115; Słysz, 2004, pp. 42-43; Uskul \& Greenglass, 2005, pp. 273-274). Proactive individuals are motivated to meet the challenges in their lives, and they commit themselves to reach high standards of the quality of their lives (Schwarzer \& Taubert, 1999, pp. 86-88).

\section{PARTICIPANTS AND PROCEDURE}

\section{STUDIED INDIVIDUALS AND RESEARCH PROCEDURE}

The research was conducted on 145 individuals aged between 60 and 85 years $(M=69.5, S D=6.74)$, involved in various forms of activity (among others, Seniors' Clubs, School of Super-Granny, and the University of the Third Age), not revealing traits of mental health disorders. For the purpose of selecting group members, it was assumed that these individuals should have their basic needs satisfied, and by means of becoming involved in new forms of activity, they could satisfy the needs of self-development and obtain satisfaction. Their activity is a particular opportunity to establish and maintain social contacts, to motivate themselves to undertake new challenges and cultivate their passions. Such a way of functioning may reflect proactive adaptation behaviours and be conducive to maintaining the quality of life. The research was of an individual character, and participation in it was voluntary and anonymous. Prior to the commencement of the research, consent was obtained, and the studied individuals were made acquainted with the objective and course of the research. From among 145 distributed sets, 94 were returned. For the further statistical analyses, 88 sets were qualified.

\section{METHODS}

In the research, the following tools were used: PCI (the Proactive Coping Inventory) and CASP-19.

The PCI, developed by Greenglass et al. (1999), in the Polish adaptation of Pasikowski et al. (2002), measures proactive remedial strategies. The PCI consists of 55 test items, expressed in the form of statements assessed in a four-degree scale (in our research, two items: 35 and 40, concerning professional activity, which was of no relevance to the studied group of individuals, were removed), and it makes it possible to 
obtain a global result, as well as resulting in seven subscales: proactive, reflective, strategic planning, preventive, searching for instrumental support, searching for emotional support, and avoidance. The psychometric properties of the Polish adaptation are similar to the indicators obtained in the original version, which means that, in spite of the intercultural differences, the inventory measures the same process. The Cronbach $\alpha$ coefficient of reliability is within the range between .67 and .87 (Pasikowski et al., 2002, p. 42).

The CASP-19 scale for measuring the quality of life of the elderly was developed by Higgs et al. (2003), and it is composed of 19 statements which the studied individuals express their opinion about using a four-degree scale $(0$ - never; 1 - seldom, 2 - sometimes, 3 - frequently). The name of the scale (CASP-19) is an acronym based on the first letters of the words denoting the measured factors: Control, Autonomy, Self-actualization, Pleasure. For the purpose of the research, the version developed by Steuden and Gamrowska (2012) was used. The CASP-19 scale makes it possible to obtain a global result, and results in the four dimensions of the quality of life: Control, Autonomy, Self-actualization and Pleasure (Higgs et al., 2003, pp. 239-252). The original version of the CASP-19 scale has satisfactory indicators of psychometric goodness. The Pearson $r$ correlation coefficient between the four dimensions was between 0.35 and 0.67 . All the dimensions have a strong latent factor load (the quality of life), remaining within the range between 0.71 and 0.88 .

In the Polish adaptation of the CASP-19 scale ( $N=346$, age: $M=69.49$ ), the following results were obtained: in the case of the general indicator $M=36.08$, $S D=7.07$ (diagonal shape $=-0.74$, kurtosis $=2.20$ ); in the scales: of Control $M=6.14, S D=2.28$, of Autonomy $M=9.08, S D=2.33$, of Pleasure $M=11.28$, $S D=2.96$, of Self-actualization $M=9.57, S D=3.27$. Polish seniors obtained a significantly lower average indicator of the quality of life (36.08 points) $(t=10.44$, $d f=648, p<.0001, F=1.228, p=.065)$ than the one obtained in the research conducted by Higgs et al. (2003, p. 43), in which this value amounted to 42.2 points $(N=286$, age: $65-75, S D=7.84)$. The indicator of the reliability (Cronbach $\alpha$ ) for the entire scale amounts to .68. Pearson's $r$ correlation coefficient between the general result and the dimensions of the scale was between .40 (Control) and .75 (Pleasure) and .77 (Self-actualization).

In the research, numerous correlations between the general indicator of the quality of life and its dimensions and psychological variables were obtained. The general results of the quality of life significantly correlate with: the general result on the wisdom scale (3D-WS M. Ardelt) $r=.39(p<.05)$; the general result on the Personal Meaning Profile Inventory of P. Wong $r=.55(p<.001)$; the global results for proactive coping (PCI Greenglass et al. 1999), $r=.39$ $(p<.05)$; the dimensions of temporal orientation AION2000 (Nosal \& Bajcar) from $r=-.20$ to $.48(p<.001)$; with time metaphors (Sobol-Kwapińska), e.g. constructive time $r=.49(p<.001)^{1}$.

\section{RESULTS}

A crucial issue was that of proving what kind of associations exist between proactive coping and the quality of life in the studied group. In order to estimate this correlation, the Pearson $r$ correlation coefficient was calculated for general results, and for particular dimensions of the CASP-19 scale, and also the PCI. The detailed results of the analysis of correlations can be found in Table 1.

The analysis of the correlation matrix in the entire group of studied individuals revealed numerous associations between the quality of life and proactive ways of coping, which are at a moderate and low level. In the case of the general result of the quality of life, and its three dimensions, they are of a positive character. The strongest correlations with proactive behaviours among the dimensions of the quality of life are those of control, pleasure, and also the general result of the quality of life (cf. Table 1).

What is more, the results of research on the scale measuring the quality of life CASP-19 were measured in two groups differentiated in terms of the global level of remedial behaviours on the PCI, presented with the interquartile range. The individuals who obtained results between 80 and $123(M=110)$ points were classified in the group with a low level of proactive coping (NPR), and those who obtained results between 148 and $197(M=162.5)$ points were classified in the group with a high level of proactive coping (WPR). The relevant data can be found in Table 2 .

\section{DISCUSSION}

The fundamental objective of the research project was to determine associations between coping with the events of daily life and the quality of life in the case of the studied elderly, involved in various forms of social activity. The results presented above corroborate the fourth hypothesis that preferences for proactive remedial behaviours co-occur with a higher quality of life in the case of the elderly, and are compatible with other reports devoted to this issue and found in gerontological literature (cf. Brzezińska \& Steuden, 2011; Bjørkløf, Engedal, Selbæk, Kouwenhoven \& Helvik, 2012; Greenglass, 2002; Halicka, 2004; Ouwehand et al., 2007; Simons, 2002; Uskul \& Greenglass, 2005).
Coping and quality of life in the elderly 
Table 1

Pearson $r$ correlation coefficients between the results on the PCI and CASP-19 in the group of studied individuals $(N=88)$

\begin{tabular}{|c|c|c|c|c|c|}
\hline $\begin{array}{c}\text { CASP-19 } \\
\mathrm{PCI}\end{array}$ & $\begin{array}{c}\text { General results - } \\
\text { quality of life }\end{array}$ & Control & Autonomy & Pleasure & $\begin{array}{c}\text { Self- } \\
\text { actualization }\end{array}$ \\
\hline $\begin{array}{l}\text { Global result - } \\
\text { proactive coping }\end{array}$ & $.40^{* *}$ & $.49^{* *}$ & .15 & $.49^{* *}$ & .06 \\
\hline Proactive & $.53^{* *}$ & $.56^{* *}$ & $.35^{* *}$ & $.48^{* *}$ & .16 \\
\hline Reflective & $.37^{* *}$ & $.43^{* *}$ & .17 & $.42^{* *}$ & .08 \\
\hline Strategic planning & $.29^{* *}$ & $.33^{* *}$ & .13 & $.28^{* *}$ & .11 \\
\hline Preventive & $.26^{*}$ & $.33^{* *}$ & .01 & $.37^{* *}$ & .06 \\
\hline Instrumental support & .03 & .18 & -.08 & .21 & -.17 \\
\hline Emotional support & .19 & $.26^{*}$ & .02 & $.36^{* *}$ & -.05 \\
\hline Coping by avoidance & .08 & .17 & -.19 & $.22^{*}$ & .04 \\
\hline
\end{tabular}

Note. ${ }^{*} p \leq .05 ;{ }^{* *} p \leq .01$

Table 2

Quality of life (CASP-19) in the groups of individuals with NPR and WPR

\begin{tabular}{lccccccc}
\hline \multirow{2}{*}{\multicolumn{1}{c}{ CASP-19 }} & \multicolumn{2}{c}{ NPR } & \multicolumn{2}{c}{ WPR } & \multicolumn{3}{c}{ Differences } \\
\cline { 2 - 8 } & \multicolumn{2}{c}{$N=23$} & \multicolumn{2}{c}{$N=22$} & & & \\
\cline { 2 - 7 } General result & 32.43 & 10.34 & 40.18 & 5.08 & -3.168 & 43 & .003 \\
Control & 5.00 & 2.81 & 7.86 & 1.91 & -3.978 & 43 & .000 \\
Autonomy & 8.17 & 2.18 & 9.09 & 2.92 & -1.190 & 43 & (not identified) \\
Pleasure & 9.74 & 2.85 & 13.23 & 1.31 & -5.239 & 43 & .000 \\
Self-actualization & 9.52 & 4.00 & 10.00 & 3.44 & -0.429 & 43 & (not identified) \\
\hline Note. NPR - a low level of global proactive coping; WPR - a high level of global proactive coping & &
\end{tabular}

\section{ASSOCIATIONS BETWEEN REMEDIAL STRATEGIES AND QUALITY OF LIFE}

Concerning the relationships between remedial behaviours and the quality of life of the elderly, the first hypothesis (H.1.), according to which proactive coping co-occurs with the satisfied needs of control, autonomy, self-actualization and pleasure, was partly confirmed, whereas the second hypothesis (H.2.), assuming a positive association between emotional support and the need of pleasure, was confirmed in the entirety of it. In turn, no confirmation for the third hypothesis, according to which it was assumed that there existed a negative association between coping by avoidance and the general indicator of the quality of life (cf. Table 1) was obtained.

The obtained results indicate that the satisfied needs of control, autonomy, and of pleasure, co-occur with the proactive form of coping in the case of the studied elderly. This may give rise to the conclusion that setting ambitious objectives for oneself independently, transforming obstacles into challenges, and also striving to become closer to perfection, and to perfect one's milieu, makes it possible for the elderly to maintain the sense of being able to exert an influence on their milieu, make choices, formulate and verify objectives, and also experience joy of life, adopt a positive attitude towards the future and the sense of the meaningfulness of life (cf. Greenglass et al., 1999; Schwarzer \& Taubert, 1999; Steuden, 2009; Trouillet et al., 2011). However, what is interesting is the lack of association between the proactive strategy of coping and satisfying the need of self-actualization connected with the sense of satisfaction with the former lifestyle, optimism, and the sense that one has energy at one's disposal. Perhaps the lack of association between the analysed variables is the result of substantial heterogeneity of the studied individuals in terms of analysed variables.

Moreover, it was found that a factor which is beneficial for satisfying the need of pleasure (and that fact had not been assumed before) and control is searching 
for emotional support which could be experienced by the studied individuals in the different forms of social involvement (Seniors' Clubs, School of Super-Granny or UTA). That is confirmed by the results of other studies which show that social support, together with the proactive form of coping, is effective, and, at the same time, adjustment strategies are conducive to the welfare of a person (cf. Greenglass, 2002; Greenglass \& Fiksenbaum, 2009; Knoll \& Schwarzer, 2006; cf. Bjørkløf et al., 2012; Meléndez et al., 2012). Social support prevents various forms of pathology because it lowers the strain connected with the stress of everyday life, makes it possible to overcome difficulties, forms the sense of resourcefulness, and, when a stress situation does occur, improves mood. Individuals who seek help in the natural networks of support (social or family ones) in which functioning is mutual and not enforced, obtain support more easily than in the case of support from institutional sources (Sęk \& Cieślak, 2006). Seeking the emotional support of friends and acquaintances (involved in similar forms of activity) creates a sense of belonging and community, activates hope, and is a source of experienced pleasure and satisfaction with staying among other people (cf. Braun-Gałkowska, 2006; Szatur-Jaworska et al., 2006). Explanation for the positive relationship between searching for emotional support and satisfying the need of pleasure may be found in the Carstensen socioemotional selectivity theory, explaining adaptation to old age. Due to the sense of narrowing the temporal horizon which is the case in the period of late adulthood, the elderly become more concentrated on positive experiences, and they also modify the scope and forms of their own activity. In social contacts, they strive to maintain such bonds with other individuals which are assessed by themselves as important in their life at the moment. Thanks to the mechanisms of selection, their contacts (relationships) with other people are less numerous in terms of their scope, but they provide more emotional satisfaction and are deeper (quoting: Janiszewska-Rain, 2005; Steuden, 2011). Undeniably, participation of the elderly in the classes taking place in Seniors' Clubs, the School of Super-Granny or the University of the Third Age (UTA) is voluntary, and, to a significant degree, is motivated by the need to broaden previously acquired information concerning various aspects of life. However, emphasis needs to be placed on the fact that the driving force behind this form of activity is the need of social integration, independence and autonomy. An interesting observation which we owe to the research is the lack of a significant association between coping by avoidance with the general quality of life. Perhaps that is connected with the fact that an avoidance strategy is of a more defensive character, because its essence is avoiding problems, and distancing oneself from difficult issues. And, even though that strategy may have an adaptation function, it clearly is not reflected in the assessment of the general quality of life.

\section{ASSOCIATIONS BETWEEN GLOBAL LEVEL OF PROACTIVE COPING AND QUALITY OF LIFE}

In the paper, the following hypothesis (H.4.) was adopted: a higher global level of proactive coping co-exists with a higher level of the sense of the quality of life. The obtained results confirm the hypothesis referred to above (cf. Table 2), and also match the reports which can be found in the literature (Bjørkløf et al., 2012; Brzezińska \& Steuden, 2011; Greenglass et al., 1999; Sęk \& Pasikowski, 2003; Słysz, 2004; Uskul \& Greenglass, 2005), in accordance with which the proactive strategies of coping (except for coping by avoidance) co-exist with the subjective indicators of health, satisfaction with life, quality of life, and optimism, in various research samples. Moreover, the analysis of the differences between the groups of people with a high and low global level of proactive coping showed that the more frequently they use the proactive forms of coping, the higher the sense of the quality of life they have (cf. Table 2). That means that for the quality of life it is beneficial to responsibly take initiatives, exercise autonomous control over one's life, and activate and gather personal and social resources, included in the scope of proactive coping. In the light of the activity theory (Neugarten, Havighurst, Tobin), explaining adaptation to old age, proactive individuals participate in social life, undertake new forms of activity, establish new relationships, base their coping with problems on their knowledge and experience, and, by means of continuous learning, acquire competences which make it possible for them to be responsible for themselves and their own old age (Steuden, 2009, 2011, p. 215; Straś-Romanowska, 2002).

\section{CONCLUSIONS}

The research presented here supports the conclusion that it is justifiable to shape the possibilities of associating and meeting of the elderly in places in which it will be possible for them to develop their interests, to participate in the exchange of social support, and also to find joy in being in the company of other people. Beyond doubt, such places are Seniors' Clubs, the School of Super-Granny or the University of the Third Age. An important form of supporting the elderly, which does not result directly from the research, but which is of significance in maintaining the activity and the welfare of them, and also for counteracting social stereotypes concerning old age, and the factors of the risk of exclusion of the elderly, is activities aiming at integration within gener-
Coping and quality of life in the elderly 
Anna Gamrowska, Stanisława Steuden ations and between them (Steuden, 2011, pp. 27-31; 138-144).

In conclusion, the presented research revealed that the quality of life, viewed as the degree of satisfying one's own needs in the case of the studied individuals, was connected with proactive remedial strategies. The fundamental restriction was the excessively non-representative research sample. The results of research presented in this paper, and the attempt to interpret them, make it possible to plan more reliable and accurate research. In order to complement the results in a comprehensive way, it would be necessary to conduct research on a larger group of seniors, taking into consideration individuals not involved in social activity as well. A valuable complement would also be broadening the repertoire of research methods by means of adding inventories devoted to the sense of the meaningfulness and value of the elderly, and also temporal orientation, which would make it possible to characterize in a holistic way, and to explain, the psychological way of functioning of the elderly, and also their adaptation to old age.

We express our gratitude to Kaja Wojciechowska, Barbara Wacko and Katarzyna Perszko for their assistance in research, and to Joanna Szafrańska and Monika Wilk for their assistance in research and translating the CASP-19 scale.

\section{REFERENCES}

Baltes, P. B., \& Baltes M. M. (1990). Psychological perspectives on successful aging: the model of selective optimization with compensation. In: P. B. Baltes, \& M. M. Baltes (eds.). Successful aging: perspectives from the behavioral sciences (pp. 1-34). New York: Cambridge University Press.

Bjørkløf, G. H., Engedal, K., Selbæk, G., Kouwenhoven, S. E., \& Helvik, A.-S. (2012). Coping and depression in old age: a literature review. Dementia and Geriatric Cognitive Disorders, 35, 121-154.

Braun-Gałkowska, M. (2006). Nowe role społeczne ludzi starszych [The new social roles of old people]. In: S. Steuden, \& M. Marczuk (eds.). Starzenie sie a satysfakcja z życia [Aging and Life Satisfaction] (pp. 183-195). Lublin: Wydawnictwo KUL.

Brzezińska, M., \& Steuden, S. (2011). Proaktywne radzenie sobie a satysfakcja $z$ życia $w$ okresie późnej dorosłości [Proactive coping and life satisfaction in late adulthood]. In: S. Steuden, M. Stanowska, \& K. Janowski (eds.). Starzenie się z godnościq [Ageing with the Dignity] (pp. 131-150). Lublin: Wydawnictwo KUL.

Diehl, M., Chui, H., Hay, E. L., Lumley, M. A., Grühn, D., \& Labouvie-Vief, G. (2013). Change in coping and defense mechanisms across adulthood: longitudinal findings in a European American Sample. Develop- mental Psychology. Advance online publication. doi: 10.1037/a0033619.

Doyal, L., \& Gough, I. (1991). A theory of human need. Hong Kong: Macmillan.

Endler, N. S., \& Parker, J. D. (1994). Assessment of multidimensional coping. Task, emotion and avoidance strategies. Psychological Assessment, 6, 50-60.

Greenglass, E. (2002). Chapter 3. Proactive coping. In: E. Frydenberg (ed.). Beyond coping: meeting goals, vision, and challenges (pp. 37-62). London: Oxford University Press.

Greenglass, E. R., \& Fiksenbaum, L. (2009). Proactive coping, positive affect, and well-being: testing for mediation using path analysis considerations. In: J. P. Ziegelmann, \& S. Lippke (eds.). Invited paper in European Psychologist. Special section on theory-based approaches of stress and coping, 14, 29-39.

Greenglass, E., Schwarzer, R., Jakubiec, S. D., Fiksenbaum L., \& Taubert, S. (1999). The Proactive Coping Inventory (PCI): a multidimensional research instrument. Paper presented at the $20^{\text {th }}$ International Conference of the STAR (Stress and Anxiety Research Society) Cracow, Poland, July 12-14.

GUS (2013). Mały Rocznik Statystyczny Polski 2013. Warszawa: Zakład Wydawnictw Statystycznych; published on the website: http://www.stat.gov.pl/ cps/rde/xbcr/gus/RS_maly_rocznik_statystyczny_ 2013.pdf (of 28.02.2014).

Halicka, M. (2004). Satysfakcja życiowa ludzi starych [Life Satisfaction of the Elderly]. Białystok: Akademia Medyczna.

Higgs, P., Hyde, M., Wiggins, R., \& Blane, D. (2003). Researching quality of life in early old age: the importance of the sociological dimension, social policy and administration. Social Policy \& Administration 37, 239-252.

Hobfoll, S. H. (1989). Conservation of resources. A new attempt at conceptualizing stress. American Psychologist, 44, 513-524.

Janiszewska-Rain, J. (2005). Okres późnej dorosłości. Jak rozpoznać potencjał ludzi w wieku podeszłym? [Late adulthood stage. How to recognise the potential of elderly people?]. In: A. Brzezińska (ed.). Psychologiczne portrety człowieka [Psychological Portraits of Man] (pp. 591-622). Gdańsk: Gdańskie Wydawnictwo Psychologiczne.

Knoll, N., \& Schwarzer, R. (2006). „Prawdziwych przyjaciół...” Wsparcie społeczne, stres, choroba i śmierć ["Real friends...". Social support, stress, illness and heath]. In: H. Sęk, \& R. Cieślak (eds.). Wsparcie spoteczne, stres $i$ zdrowie [Social Support, Stress and Health] (pp. 29-48). Warszawa: Wydawnictwo Naukowe PWN.

Lazarus, R., \& Folkman, S. (1984). Stress, appraisal and coping. New York: Springer.

Lazarus, R. (1986). Paradygmat stresu i radzenia sobie [The Paradigm of Stress and Coping]. Nowiny Psychologiczne, 3-4, 2-39. 
Maslow, A. (1943). A theory of human motivation. Psychological Review, 50, 370-396.

Meléndez, J. C., Mayordomo, T., Sancho, P., \& Tomás, J. M. (2012). Coping strategies: gender differences and development throughout life span. The Spanish Journal Of Psychology, 15, 1089-1098.

Oleś, M. (2010). Jakość życia mtodzieży w zdrowiu $i$ w chorobie [Quality of Life in Adolescence - in Health and Disease]. Lublin: Wydawnictwo KUL.

Ouwehand, C., De Ridder, D. T. D., \& Bensing, J. M. (2007). A review of successful aging models: proposing proactive coping as an important additional strategy. Clinical Psychology Review, 27, 873-884.

Pasikowski, T., Sęk, H., Greenglass, E., \& Taubert, S. (2002). The proactive coping inventory - Polish adaptation. Polish Psychological Buletin, 33, 41-46.

Ryff, C. D., \& Singer, B. (2004). Paradoksy kondycji ludzkiej: dobrostan i zdrowie na drodze ku śmierci [Ironies of the human condition: well-being and health on the way to morality]. In: J. Czapiński (ed.). Psychologia pozytywna. Nauka o szczęściu, zdrowiu, sile i cnotach człowieka [Positive Psychology. The Science of Human Happiness, Health, Strength and Virtues] (pp. 147-162). Warszawa: Wydawnictwo Naukowe PWN.

Schwarzer, R., \& Taubert, S. (1999). Radzenie sobie ze stresem: wymiary i procesy [Coping with stress: Dimensions and processes]. Promocja Zdrowia, Nauki Spoteczne i Medycyna, 17, 72-92.

Sęk, H., \& Cieślak R. (2006). Wsparcie społeczne sposoby definiowania, rodzaje i źródła wsparcia, wybrane koncepcje teoretyczne [Social support how to define, the types and sources of support, selected theoretical concepts]. In: H. Sęk, \& R. Cieślak (eds.). Wsparcie spoteczne, stres i zdrowie [Social Support, Stress and Health] (pp. 11-28). Warszawa: Wydawnictwo Naukowe PWN.

Sęk, H., \& Pasikowski, T. (2003). Proaktywne strategie radzenia sobie ze stresem życiowym a subiektywne wskaźniki zdrowia [Proactive Coping and Subjective Health Indicators]. Studia Psychologiczne, 41, 105-126.

Simons, C. M. (2002). Proactive coping, perceived self-efficacy, and locus of control as predictors of life satisfaction in young, middle-aged, and older adults. Dissertation Abstracts International: Section B: The Sciences and Engineering, 63 (3-B), 1590.

Słysz, A. (2004). Refleksyjność, proaktywne radzenie sobie ze stresem życiowym a zdrowie [Reflexivity, proactive coping and health]. In: Ł. Kaczmarek, \& H. Sęk (eds.). W stronę psychologii pozytywnej [Toward a Positive Psychology] (pp. 31-48). Poznań: Bogucki Wydawnictwo Naukowe.

Steuden, S., \& Gamrowska, A. (2012). Polskie opracowanie skali do badania jakości życia osób starszych CASP-19, autorstwa P. Higgsa, M. Hyde, R. Wigginsa, D. Blane [Polish development Older Peo- ple's Quality of Life Questionnaire CASP-19, by P. Higgs, M. Hyde, R. Wiggins, D. Blane]. Lublin. Katedra Psychologii Klinicznej. Wersja eksperymentalna. Do użytku wewnętrznego.

Steuden, S. (2009). Szczęśliwi po pięćdziesiątce [Happy in Their Fifties]. Warszawa: Wydawnictwo Akademickie i Profesjonalne Sp. z o.o.

Steuden, S. (2011). Psychologia starzenia się i starości [Psychology of Ageing and Old Age]. Warszawa: Wydawnictwo Naukowe PWN.

Steuden, S., \& Marczuk, M. (2006). Wstęp [The Introduction]. In: S. Steuden, \& M. Marczuk (eds.). Starzenie się a satysfakcja z życia [Aging and Life Satisfaction] (pp. 9-14). Lublin: Wydawnictwo KUL.

Straś-Romanowska, M. (2002). Późna dorosłość. Wiek starzenia się [Late adulthood. The period of ageing]. In: B. Harwas-Napierała, \& J. Trempała (eds.). Psychologia rozwoju człowieka [Psychology of Human Development] (Vol. 2, pp. 263-293). Warszawa: PWN.

Straś-Romanowska, M. (2005). Jakość życia w świetle założeń psychologii zorientowanej na osobę [Quality of life in the light of person-oriented psychology]. Kolokwia Psychologiczne, 13, 263-274.

Szatur-Jaworska, B., Błędowski, P., \& Dzięgielewska, M. (2006). Podstawy gerontologii społecznej [Principles of Social Gerontology]. Warszawa: Oficyna Wydawnicza ASPRA-JR.

Trouillet, R., Doan-Van-Hay, L. M., Launay, M., \& Martin, S. (2011). Impact of age, and cognitive and coping resources on coping. Canadian Journal on Aging, 30, 541-550.

Uskul, A. K., \& Greenglass, E. (2005). Psychological well-being in a Turkish-Canadian sample. Anxiety, Stress and Coping, 18, 169-178.

Wrześniewski, K. (2000). Style a strategie radzenia sobie ze stresem. Problemy pomiaru [Styles and strategies of coping with stress. measurement issues]. In: I. Heszen-Niejodek, \& Z. Ratajczak (eds.). Człowiek w sytuacji stresu [Human Being in the Situation of Stress] (pp. 44-64). Katowice: Wydawnictwo Uniwersytetu Śląskiego.
Coping and quality of life in the elderly 